\title{
THE DUTY OF THE CORPORATE OFFICER ON EXAMINATION FOR DISCOVERY AND THE USE OF HIS EVIDENCE AT TRIAL
}

\section{HARVEY LOCKE*}

The author provides an analysis of the case law that has developed around the rules of court which allow corporate officers and corporate employees to be examined for discovery. Mr. Locke sets the purpose and nature of a corporate officer's evidence opposite that of an employee, or a former employee, to demonstrate that the former is normally binding on the corporate party, while the latter is normally only some evidence which can be used against the corporate party, but nonetheless evidence which the corporate party is free to deny. Next, the situation of whether a person is speaking as an employee or on behalf of the corporation is reviewed. The position in Alberta with respect 10 these issues is compared and contrasted to the position in Ontario. As well, the current Alberta position is compared with the interpretation that formerly prevailed. Afier this review and analysis of the development of the law. the duty of an officer appointed under the rules of court to speak on behalf of a corporate party is reviewed with respect to the officer's duties in relation to preparing for the examination for discovery of the corporation. These include an analysis of whether the corporate officer must interview employees, review the transcripts of other witnesses previously examined, and comment upon statements made by employees and others during their examinations for discovery.
L'auteur analyse le droit jurisprudentiel qui émane des décisions du tribunal permettant aux dirigeants et aux employés des sociétés de subir un interrogatoire au préalable. Locke oppose l'objet et la nature du témoignage apporté par le cadre d'une société et ceux d'un employé ou ancien employé de la même société; il démontre que le premier engage normalement la responsabilité de la société, tandis que le second ne constitue que des éléments de preuve qui peuvent certes incriminer la société mais que celle-ci est libre de nier. Il examine ensuite si le témoin parle en tant qu'employé ou au nom de la société. La position de l'Alberta sur le sujet contraste avec celle de I'Ontario. L'approche actuelle de l'Alberta est analysée à la lumière de l'interprétation qui prévalait auparavant. Après avoir étudié l'évolution du droit, il examine quel est le devoir d'un dirigeant appelé par décision du tribunal à parler au nom de la société par rapport aux devoirs d'un dirigeant qui se prépare à un interrogatoire au préalable pour la société. Il se demande si le dirigeant de la société doit entendre les employés, examiner les transcripts des autres témoins déjd interrogés et faire des commentaires sur les déclarations produites par les employés au cours de l'interrogatoire au préalable.

\section{TABLE OF CONTENTS}

I. INTRODUCTION $\ldots \ldots \ldots \ldots \ldots \ldots \ldots \ldots \ldots \ldots \ldots \ldots$

II. THE PURPOSE OF THE OFFICER'S EVIDENCE $\ldots \ldots \ldots \ldots \ldots \ldots$

A. THE NATURE OF OFFICERS' EVIDENCE

AS OPPOSED TO EMPLOYEES' EVIDENCE . . . . . . . .

B. THE DUAL ROLE OF A WITNESS AS

BOTH OFFICER AND EMPLOYEE ..............

C. THE USE OF THE OFFICER'S EVIDENCE AT TRIAL $\ldots \ldots$

D. THE PROBATIVE VALUE OF EVIDENCE

GATHERED PURSUANT TO RULE 214(1) $\ldots \ldots \ldots \ldots \ldots$

1. Evidence Relating to Information Gathered

From Employees and Others Pursuant to Rule 200(1) ...... 
(a) Modern Alberta Law, the Nova Case . . . . . . . . 928

(b) Ontario Law . . . . . . . . . . . . . . 933

(c) The Old Alberta Case of Edmonton v. W.W. Sales ..... 935

(d) The Use of a Notice to Admit Facts . . . . . . . . 936

(e) Conclusion Regarding Information From Employees ..... 937

2. Evidence Relating to Information Gathered

From Others Not Within the Scope of Rule 200(1) . . . . . 937

III. DUTIES OF THE OFFICER APPOINTED PURSUANT TO RULE 214(2) IN RESPECT OF INFORMATION FROM EMPLOYEES . . . . 940

A. PREPARATION BY INTERVIEWING EMPLOYEES . . . . . . . 940

B. PREPARATION BY READING THE TRANSCRIPTS OF EMPLOYEES WHO HAVE BEEN EXAMINED $\ldots \ldots \ldots \ldots .943$

C. ADOPTING AS FACT THE EVIDENCE OF EMPLOYEES WHO HAVE BEEN EXAMINED $\ldots \ldots \ldots \ldots .945$

D. STATING WHETHER THE

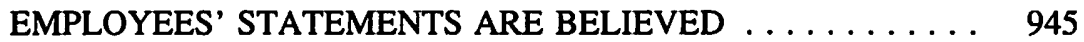

E. STATING THE COMPANY'S POSITION

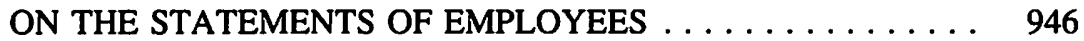

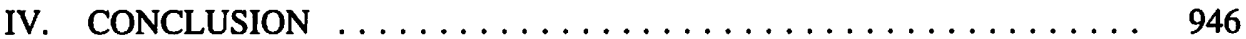

\section{INTRODUCTION}

Many significant litigation files involve examining corporate employees, as well as a corporate officer, for the purpose of gathering evidence from a corporate litigant. It is therefore surprising how much uncertainty there is in this area of the law, and how little the scope of an officer's duty on examination for discovery is understood.

This article examines the current state of the law in Alberta and contrasts it with Ontario where the law seems to be taking a different course. Both jurisdictions have had recent Court of Appeal decisions relevant to this area of the law but Alberta law has the added complication of conflicting decisions at the trial level.

\section{THE PURPOSE OF THE OFFICER'S EVIDENCE}

\section{A. THE NATURE OF OFFICERS' EVIDENCE AS OPPOSED TO EMPLOYEES' EVIDENCE}

The starting points are sub-rules (1) and (2) of Alberta Rule of Court 214. ${ }^{1}$ They provide:

214.(1) Any party to an action or issue may at the trial or on motion use in evidence as against any opposite party any part of the examination of that opposite party, or in case the opposite party is a corporation, of the examination of any officer thereof selected to submit to an examination to be so used.

I. Alberta Rules of Court, r. 214. 
(2) The selection shall be made by the corporation within five days after a demand for the making of the selection has been served upon it or its solicitor, or by the Court if the corporation refuses or fails to select any or what the Court considers the proper officer or officers having regard to the question that is involved.

Rule 214(1) thus states that the purpose of the officer's testimony is to give evidence which may be used at trial, or on motions, against the corporation who selects him as its officer. Rule 214(1) is in contrast to Rule 200(1). It provides: ${ }^{2}$

200.(1) Any party to an action, any officer of a corporate party and any person who is or has been employed by any party to an action, and who appears to have some knowledge touching the question at issue, acquired by virtue of that employment..., may be orally examined... before the trial of the action touching the matters in question by any person adverse in interest, without order.

The major difference between Rule 214(1) and Rule 200(1) is that Rule 214(1) provides that the appointed officer's evidence can be used at trial against the party producing him. Rule $200(1)$ is silent as to the use to which evidence gathered through it may be put.

In Opron Construction Co. v. Alberta, ${ }^{3}$ Mr. Justice Dea discussed the difference between an officer's evidence taken on an examination for discovery pursuant to Rule 214(1) and evidence taken on an examination for discovery from employees pursuant to Rule 200(1). He said: ${ }^{4}$

It is rule 214 which authorizes the use of the answers given on discovery by the selected officer of a corporate party against that party. So here the discovery of Nicolson, the selected officer, may be used as evidence against the defendant. The discoveries of Thiessen, Ruttan and Campbell, not being discoveries of a party or of a selected officer of a party, are not available for such a purpose. Only if these employees give evidence at the trial will the plaintiff be able to make use of their discoveries and then only for the purpose of cross-examinations. The discoveries of these employees may be used in other ways, as will become apparent, but cannot be used directly as evidence against the defendant.

In Cana Construction Co. v. Calgary Centre for Performing Arts, ${ }^{5}$ Kerans, J.A. discussed the difference between an officer examined pursuant to Rule 214(1) and an officer examined pursuant to Rule 200(1). He said: ${ }^{6}$

A distinction must be made between the use of the 'officer' in Rule 200 and in Rule 214. Rule 200 affords the party opposite an opportunity to discover in advance the evidence to be given at trial by likely witnesses. The purpose of the other Rule is not merely to gain information but to gain formal admissions from the party opposite.

The issue in that case was whether a volunteer could be an officer for the purpose of Rule 200(1). It was held that he could.

In Yanik v. Conibear, ${ }^{7}$ MacDonald, J. said of employees' evidence: ${ }^{8}$

Ibid. r. 200(1).

Opron Construction Co. v. Alberta (1988), 85 A.R. 143 (Alta. Q.B.), aff'd in part, (1989), 100 A.R. 58 (Alta. C.A.).

Ibid. at 145.

Cana Construction Co. v. Calgary Centre for Performing Arts (1986), 71 A.R. 158 (Alta. C.A.).

Ibid. at 159, per Kerans, J.A.

Yanik v. Conibear, [1944] 1 W.W.R. 548 (Alta. S.C.), affd without reasons, [1944] 3 W.W.R. 395 (C.A.).

Ibid. at 550, per MacDonald, J. 
This evidence is not, of course, the evidence of the defendant company and cannot be used against it at trial. On the other hand, the evidence of the defendant company, obtained through the medium of Broderick, its proper officer in that behalf, may be read against the company on the trial.

\section{B. THE DUAL ROLE OF A WITNESS AS BOTH OFFICER AND EMPLOYEE}

Almost invariably the officer selected pursuant to Rule 214(2) is also an employee of the company. This raises a question of whether there should be a differentiation between his evidence in his capacity of officer and his evidence in his capacity as employee, or whether his evidence should all be treated as the company's evidence. This issue was discussed by Côté, J.A. in Opron. ${ }^{9}$ On the threshold question of whether the officer testifies once as officer and then again as employee, His Lordship said: ${ }^{10}$

It is customary for an officer with personal knowledge to answer once only, not first as an employee and then over again as corporate spokesman.

The use of that evidence is discussed below.

\section{THE USE OF THE OFFICER'S EVIDENCE AT TRIAL}

Rule 214(1) is clear in stating that evidence gathered pursuant to it may be used at trial. There is, however, a judicial debate whether or not all of it can be read in, and whether it all constitutes binding admissions.

In Pelican Oil \& Gas Co. v. Nor. Alta Gas \& Dev. Co., ${ }^{11}$ Beck J.A. said: ${ }^{12}$

In the case of a corporation being the party, the examination of the corporation is by way of an examination of an officer selected by the company or selected by a Judge, if the corporation refuses or fails to select any or what the Judge considers the proper officer or officers having regard to the questions involved. Any part of the examination of any officer or officers so selected may be used as evidence at the trial against the corporation.

In Nova v. Guelph, ${ }^{13}$ Brennan, J. said of Rule 214(1):

Paraphrasing the rule, it provides that any part of the examination for discovery of an officer of a corporation who has been selected by it to submit to examination for discovery may be used at the trial against the corporation by an opposite party.

In Edmonton v. Hawrelak, ${ }^{14}$ Kirby, J. said of Rule 214(1):

I construe this rule as providing that all answers given by an officer of a corporation, selected by that corporation for examination for discovery by the opposite party, are admissible at trial, as evidence binding against the corporation.

These three passages suggest that Rule 214(1) should be taken literally. In other words, anything which the officer answers at examination for discovery can be used at trial. I will call this the literal approach.

9. Supra, note 3.

10. Ibid. at 63, per Côté, J.A.

11. Pelican Oil \& Gas Co. v. Nor. Alta. Gas and Dev. Co., [1918] 1 W.W.R. 957 (C.A.).

12. Ibid. at 963, per Beck, J.A.

13. Nova v. Guelph (1986), 57 Alta. L.R. (2d) 15 (Alta. Q.B.), per Brennan, J.

14. Edmonton v. Hawrelak, [1972] 2 W.W.R. 561 at 573 (Alta. S.C.). 
In Opron, ${ }^{15}$ Dea, J. criticized the literal approach. In essence he said that not every part of an examination for discovery of a corporate officer can be read in at trial because what he may be asked on discovery is not as constrained by relevance as is that which is admissible at trial. (This part of his judgment was not commented on by the Court of Appeal.) In specific reference to Kirby, J.'s comment in Hawrelak ${ }^{16}$ that all evidence may be read in at trial as binding on the corporation, Dea, J. said: ${ }^{17}$

The issue [the use of evidence gathered pursuant to rule $214(1)$ at trial] is not so easily resolved as what may be asked on a discovery is wider and is to be given more latitude than what might be admissible at trial.

Dea, J. referred to an unreported decision of Miller, J. in Curlett v. Steele, ${ }^{18}$ to illustrate a problem with the literal approach to 214(1). In Curlett, Miller, J. was faced with a situation where there were four possible dates for the valuation of assets. $\mathrm{He}$ refused to decide which was the relevant date for the purpose of restricting the scope of examination for discovery. He said that was a decision for the trial judge and that:

I do not think I should usurp that function and in the same vein I do not think I should permit anything to be done, leading up to the trial, which would have the effect of limiting access by any of the parties to information which could fall within the boundaries set out by Haddad, J.A. in the Czuy case,... namely do the contentious questions touch 'the matters in question', or are they 'questions which may be permitted on cross-examination'. If they fall within either of these categories they are to be answered on examination for discovery.

Dea, J. suggested a more complex approach to the interpretation of Rule 214(1) than the approach followed by Kirby, J. He said: ${ }^{19}$

\begin{abstract}
It seems to me that the apparent conflict raised by a consideration of the Alberta Rules in conjunction with the decisions of the court concerning questions which may be put on discovery may be resolved in this way: The general rule is that questions and answers on discovery of a party or (where corporations or the Crown are involved) of the selected officer of a party are admissible in evidence against that party under rule 214. Objections to questions which may arise during the discovery are to be pursued and resolved in the course of the discovery pursuant to rules 203,210 and 213 and are not to be delayed and addressed at trial.
\end{abstract}

To this general rule there is an exception that applies at least to this extent: Where a party has objected to questions during the discovery on the grounds of relevancy and the judge to whom the objection is appealed refuses the objection on the basis that the court will not conduct a minute examination of each question to determine its relevancy, then notwithstanding nule 214 , the party against whom use of the discovery is proposed is free to apply to the trial judge as indicated in Curlett v. Steele.

The basis for this exception is that the judge who considered the objection at the time of the discovery did not rule on the issue of relevance at all but ordered the questions to be answered because they might be relevant. At trial the issue of relevance will be finally resolved and with it any issue of admissibility hanging over from discovery.

Thus, under Dea, J.'s rule, evidence obtained from the officer may be read in at trial unless an objection on the grounds of relevance was taken at discovery, pursued to chambers, and overruled by the chambers judge on the basis that the relevancy of the evidence is better left to be decided by the trial judge.

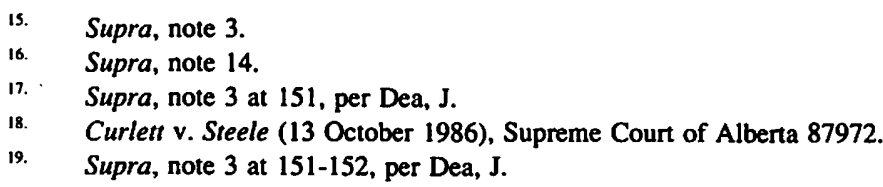


Dea, J.'s rule appears to me to be a better interpretation of the use of evidence obtained under Rule 214(1) than the literal approach of Kirby, J. In my respectful view it takes better account of the difference between discovery and trial. I think another court would follow it over Kirby, J.'s literal approach. My research has not disclosed that any court has yet been faced with the choice.

Dea, J.'s formulation applies well to the situation where an objection is taken and no answer provided, which then provokes a chambers application to compel an answer. It does not address a situation I have experienced where a lawyer objects to a question, and then says that he will allow his client to answer it on the understanding that he will not admit the relevance of the question at trial. In such circumstances the lawyer is arguably doing what a chambers judge would order in any event. If that is so, then any information so gained would not automatically be useable at trial, unlike the other evidence obtained from the officer. However, it could be argued on the basis of Dea, J.'s comments that the objection should be made and dealt with before trial in chambers so far as counsel are concerned, and that only a judge, upon hearing the application, can order that the question of relevancy be deferred to the trial judge. The difficulty with this argument is that it would promote chambers applications, instead of saving the court's time.

I am inclined to the view that the objection which is deferred to trial will be viewed as a proper objection which makes an issue for the trial judge of the use of that portion of the discovery transcript which relates to the question objected to.

\section{THE PROBATIVE VALUE OF EVIDENCE GATHERED PURSUANT TO RULE 214(1)}

1. Evidence Relating to Information Gathered From Employees and Others Pursuant to Rule 200(1)

\section{(a) Modern Alberta Law, The Nova Case}

The most frequently referred to Alberta case on this issue is Nova v. Guelph. ${ }^{20}$ In that case, Brennan, J. was urged to make a number of choices. He was urged by the Plaintiff, against whom employees' evidence was sought to be used, to hold that employees' evidence was worthless as evidence against the corporation, and that the only purpose of such evidence was to discover information..$^{21}$ He was urged by the defendant, seeking to read that evidence in against the plaintiff corporation, that it be considered an admission against the Plaintiff corporation and conclusive proof of the facts. ${ }^{22} \mathrm{He}$ was

Supra, note 13. The Nova case was exhaustively reargued on appeal but no appeal was made from this ruling which occurred during the course of the trial and which has not yet been judicially considered. A review of the transcript of the arguments made by counsel in that case is helpful because they were well prepared and aired the issue fully.

21. See the discussion of Edmonton v. W.W. Sales, infra at text associated with note $45 \mathrm{ff}$.

22. See the discussion of Edmonton v. Hawreluk, supra at text associated with note $14 \mathrm{ff}$ and note 23 ff. 
presented with authorities to support both propositions. He took a middle course and ruled that once the plaintiff's officer admitted that the evidence given by the employee was the company's information then:

...the defendant may make the same use of the examinations for discovery of the employees of the Plaintiff as a part of the examination for discovery of Olafson [the officer] as it is entitled to make of any other part of such examination.

Brennan, J. recognized that this statement raised the question of what effect is to be given to such evidence. He took pains to be clear that this evidence is not conclusive proof which is binding against the plaintiff contrary to what Kirby, J. had decided in the Hawrelak case. ${ }^{23}$ In Hawrelak the issue was whether the evidence given on discovery of the officer of the City of Edmonton which contained information he obtained from other officers of the city could be read in at trial. In ruling that it could be read in Kirby, J. said: ${ }^{24}$

I construe this rule as providing that all answers given by an officer of a corporation, selected by that corporation for examination for discovery by the opposite party, are admissible at trial, as evidence binding against the corporation.

Brennan, J. reinterpreted Kirby, J.'s decision in Hawrelak, and said that if his reinterpretation is wrong, then he disagrees with Kirby, J. Brennan, J. said of Kirby, J.'s ruling: ${ }^{25}$

His ruling, however, that such evidence was binding against the corporate plaintiff creates a problem for me. If in stating that such evidence was binding against the corporate plaintiff, he meant that the evidence was simply conclusive proof against it that it had received that information, I agree. If, however, Kirby $\mathrm{J}$. in making such ruling meant that the facts related in such information were conclusively proved against the corporate plaintiff, I must with the greatest respect disagree. If the latter was the case, a corporation would be precluded from asserting or from calling evidence to establish that such information was false or inaccurate. A corporation could well be in a position where two different employees who had knowledge of the same event gave conflicting versions with respect thereto, and it would be impossible to determine which version should prevail to bind the corporation. Further, a corporation would be bound to disclose information from a disgruntled employee who for reasons best known to himself could well give false information as to the material events which would be harmful to the corporation's case and with respect to which events the corporation may be possessed of very strong and convincing evidence which proved the falsity of the information given by such employee. If such false information were considered to be conclusively proved against the corporation, it would be precluded from attempting to prove that they were indeed false, and it would thereby suffer a great injustice. These are just two examples of the problems and of the injustices which might arise if such interpretation or effect was given to $R$. 214(1). It is my view that this is not the effect which should be given to the rule and that it was not intended that it be given this effect.

Brennan, J. enunciated the principle which he would use for the evidence of employees. He said: ${ }^{26}$

It is my finding in this regard that a corporation is bound by the disclosure that it received the information in question, but it is entitled to assert that such information is false or inaccurate and to attempt by other evidence to prove itself.

It is my further finding that what Kirby $\mathrm{J}$. found in Hawrelak and what I have found in this case to be admissible in evidence against a corporation is simply evidence of the facts contained therein, and, as is

Ibid. at 573.

Supra, note 13 at 21 .

Ibid. at 22. 
the case with any other evidence, should be given the weight which the trier of fact, be it judge or jury, considers proper having regard to all of the circumstances of the case.

Thus, in Brennan, J.'s view, information which an officer obtains from employees which is given in response to questions on examination for discovery is only evidence of the facts. It is not conclusive proof of the facts in the sense of it being an admission binding on the corporation whose officer gave that information on discovery.

Support for Brennan, J.'s view is arguably found in the comments of Côté, J.A. in Opron. ${ }^{27}$ There, Côté, J.A. addressed the situation which might arise if the officer's knowledge and that of the corporation differ. He said: ${ }^{28}$

At times his knowledge and that of the corporation may differ. His memory of a certain event may conflict with the memories of all the other employees of the corporation, for example. It is true that opposing counsel could make the corporation admit that its officer's memory was among the pieces of information which it had; whereas the opponent probably could not make it say that its officer's opinion formed any part of its own opinion.

Thus the officer's personal knowledge is only one of the pieces of information the corporation has. Even the officer's evidence is not an admission in Côté, J.A.'s view. This is implicitly consistent with Brennan, J.'s approach in Nova, which holds that all evidence read in based on information from employees is merely some evidence, not an admission. However, no express reference is made to the Nova case in Opron and Côté, J.A. made it clear that he was not commenting on the use at trial of officer's evidence based on information from employees.

In Nova, Brennan, J. found support for his views on the use of an employee's evidence at trial from an earlier decision of the Alberta Court of Appeal in MacGregor v. C.P.R. ${ }^{29}$ Interestingly, Kirby, J. also relied on MacGregor in his decision in Hawrelak.

In the MacGregor case an employee of the CPR had said he pushed the train out. The CPR's officer was then asked "Is that in fact what happened?" The reply came that that was all the information the CPR had. The examining lawyer then pushed further. He said "I am entitled to get the CPR's position, I want to know whether the CPR accepts the conductor's statement." The CPR's counsel replied that the CPR "neither accepts nor rejects it." It refused to say more.

The Alberta Court of Appeal agreed with that approach. Harvey, C.J.A. said: ${ }^{30}$

What he answered in this case was, we think, correct and all that could be required.

Harvey, C.J.A. made an important statement in respect of an officer's duty regarding facts which are the key facts in establishing the Plaintiff's cause of action. He said: ${ }^{31}$ 
As to the facts which the action is brought to establish [the officer] cannot be expected or required to give any statement of what the fact is.

He further stated: ${ }^{32}$

If he were compelled to do so and that were carried to its limit, there might be no necessity for a trial at all, the jury would have nothing to do except formally to record a verdict because the admissions might cover everything. The Rule does not require that. It is the function of the jury or the Judge, not the party, to decide what the true facts in dispute are.

Although he does not mention a rule number in his judgment, it is apparent that Harvey, C.J.A. was speaking of the equivalent rule to present-day Rule 214(1).

Brennan, J.'s decision in Nova may be summarized as follows:

1. An officer's testimony on discovery respecting information obtained from employees which is said to be information of the company may be read in at trial as evidence which tends to prove a fact.

2. Such information is not binding evidence against the corporation. In other words, it is not an admission which conclusively proves the fact. The corporation may call evidence which tends to disprove the fact and it will be up to finder of facts (the judge or jury) to decide if the fact is proven.

I will call this the Nova approach. ${ }^{33}$ The practical result of the Nova approach is that once the officer answers that the corporation has no information contrary to the employee's evidence then absent some witness testifying to the contrary at trial, the fact is likely to be found proven by the trial judge or jury.

There is a big difference between reading in such evidence pursuant to the Nova approach as opposed to having that evidence by way of an admission as suggested in Hawrelak. In the case of the read-in information under the Nova approach, one cannot rely on the fact being proven until both cases are closed at trial. By contrast, in the case of an admission, one can make such a reliance. The Nova approach, therefore, requires counsel to interview all potential witnesses before the trial, regardless of how helpful the evidence of the officer appears to be, to find out what those witnesses would have to say if they were called to testify at trial. Otherwise, counsel could be surprised at trial. One possible approach to avoiding such a surprise, apart from interviewing all witnesses, would be to obtain an undertaking at discovery from the officer to advise of any contrary information which comes to light before trial.

The Nova decision may be distinguishable. In addition to his ruling regarding the general law of examinations for discovery, Brennan, J. also based his decision on the admissibility of employee's evidence on a second and very different approach. At discovery there was a discussion between counsel in Nova in which the plaintiff

33. A useful discussion of the Nova approach is found in Robert W. Thompson's "Practise Note on Discovery Rules" (1986), 57 Alta. L.R. (2d) 23. 
Corporation's counsel agreed that all the evidence given by the plaintiff's employees was information of the plaintiff Company. This discussion is quoted in Brennan, J.'s decision, and was as follows: ${ }^{34}$

Mr. Tavender: Secondly, I would like to confirm for the record that you are not willing to agree to our use of the discovery of any employee of Nova on the basis that at trial, on any basis, we had proposed to use some variation or agreement that might shorten the discovery of the officer, and I gather we do not have an agreement on that and just proceed under the Rules of Court.

Mr. Hunter: I am not clear on what you are proposing, Mr. Tavender, and if you want me to indicate whether I agree with it or not, I think you better be specific. I made it clear to you that the position that we take on the examination of the plaintiff that you have examined 68 Nova employees and former employees, we have produced many, many documents. Nova has presented Mr. Olafson as the officer for the purpose of examination for discovery. Insofar as Mr. Olafson has personal knowledge, he will answer. Insofar as he has knowledge that he has acquired by way of inquiry or as a result of statements and examination for discovery of employees and former employees of Nova, that is the information of the officer. The company will neither accept nor reject information so described, as it is not obliged to under the rules and under the cases as I understand them in this jurisdiction.

Mr. Tavender: Will Mr. Olafson admit on a, let's call it a blanket basis of information of Nova the questions and answers given by the employees in the course of their discoveries?

Mr. Hunter: The company admits that the answers to the questions asked by the employees and former employees of Nova constitute the information of the company.

Mr. Tavender: And can be used to the extent that information in law can be used without the necessity of each and every one of those questions and answers being put to Mr. Olafson and that way made use of to the extent the law permits.

Mr. Hunter: Let me put it this way, I am not sure if it's responsive to what you are proposing, because I don't know what you are proposing: Mr. Olafson is quite prepared as the officer the plaintiff to say that in the case of these 68 employees or former employees that have been examined, that the answers given to the questions asked constitute his information. If that's suitable for your purposes. The other way you can do it is you can ask him to look at every question and every answer and ask him if that is his information, and he will say, "That is my information". You can do it that way or you can say every answer to every question is the information of the officer.

Brennan, J. considered this exchange between counsel to be an agreement on the use of discovery evidence which brought this case within a passage from Pelican ${ }^{35}$ where Beck, J.A. said ${ }^{36}$

The examination of an employee, whether of an individual party or of a corporation (other than the selected officer) cannot be used as evidence - but only as a source of information - except that if it be made to appear that the party examining for discovery has after due diligence been unable to obtain the attendance at the trial of the person examined, or if for any other reason it appears to be just and convenient, the Court or Judge may permit the whole or any part of the examination of such employee to be used in evidence.

\section{In Nova, Brennan, J. said: ${ }^{37}$}

In this regard, it is my further view that if I did not find as I have, the discussion referred to would bring this case within the situation contemplated by Beck J., who in delivering the judgment of the majority in the Pelican Oil \& Gas case, stated at p. 963:

"...if for any other reason it appears to be just and convenient, the Court or Judge may permit the whole or any part of the examination of such employee to be used in evidence." [emphasis Beck J.'s] 
In the result, the defendant may make the same use of the examinations for discovery of the employees of the plaintiff as a part of the examination for discovery of Olafson as it is entitled to make of any other part of such examination.

Thus, it may be possible to distinguish the Nova case based on this agreement, leaving it open to counsel to argue in favour of some other approach to the use of employee's evidence which has been put to an officer on examination for discovery.

\section{(b) Ontario Law}

The Nova approach may be contrasted to the Ontario approach, which is similar to Kirby, J.'s approach in Hawrelak. ${ }^{38}$ In Claiborne Industries Ltd. v. National Bank of Canada, ${ }^{39}$ the Ontario Court of Appeal placed the onus on the officer to identify any information the company has received from employees with which it disagrees, failing which any information from employees given by the officer on discovery constitutes an admission which can be read in against the corporation at trial.

The Ontario Court of Appeal ${ }^{40}$ based its reasoning on the English Court of Appeal's judgment in Welsbach Incandescent Gas Lighting Co. v. New Sunlight Incandescent Co., ${ }^{41}$ where the Master of the Rolls, in obiter, said: ${ }^{42}$

It seems to me that, whether it be an individual who has to obtain information from his servants, or a company which answers by its secretary or manager, who has also to obtain information from other officials of the company, the reason why the answer can be read against the party interrogated is that, when it has been given according to the principle which I have indicated, it is a statement on behalf of that party by which he is bound. I do not mean that a case might never arise in which a person answering on behalf of a company could not protect himself in some way by the form of his answer.

Of this passage, Carthy, J.A. said: ${ }^{43}$

I adopt the suggestion put forward by the Master of the Rolls, to the effect that it should be incumbent upon the party answering questions to identify any reservations as to accuracy or any reason that the answers are not being adopted, including answers based on information received from persons who are not in the employ of the party.

Our rules are designed for efficiency in the exchange of information and admissions which will shorten the trial. In practice it is customary to assume that anything in the discovery of an opposite party which speaks against that party's case will qualify for admission at trial. The deponent knows the source of the information and whether the party on whose behalf it is offered is prepared to live with that information as reflecting the truth for purposes of the issues before the court. It is simple enough for a witness to provide information and then qualify any reliance. An oversight can be covered by a letter written after discovery. When information is provided without comment, it is only fair and proper that the parties use apparent admissions to measure the distance between them on the issues.

Thus, as a result of the Claiborne case, there is a marked difference in the use of examinations for discovery between Ontario's approach and Alberta's Nova approach. In Claiborne, the Ontario Court of Appeal established that an employee's information binds the company unless it is expressly rejected. In Nova, an employee's information

Supra, note 14.

39. Claiborne Industries Ltd. v. National Bank of Canada (1989), 59 D.L.R. (4th) 533 (Ont. C.A.).

40. Ibid.

41. Welsbach Incandescent Gas Lighting Co. v. New Sunlight Incandescent Co., [1900] 2 Ch. 1 (C.A.).

42. Ibid. at 9.

43. Supra, note 39 at 545 . 
was said to be only some evidence. It is worth looking at what might be the reasons for the difference.

First, Ontario law has not always been that way. In the trial decision of Claiborne, ${ }^{44}$ Ewaschuk, J. had a very different view of the use to which the officer's discovery might be put. He applied a much narrower standard, saying that no hearsay evidence would be ordinarily admissible at trial, and thus information from former employees told to the officer is inadmissible as hearsay, unless it meets an exception to the hearsay rule.

He based his decision in part on his interpretation of the Alberta case of Edmonton $\mathbf{v}$. W.W. Sales Ltd. $^{45}$ Of the Edmonton v. W.W. Sales case, he said: ${ }^{46}$

The Edmonton judgement, however, did deal with the examination for discovery of a corporate officer. This case expressly refers to the Black judgment, ${ }^{47}$....in holding that the answers on discovery of a corporate officer did not bind the company as to information received from company servants since the company had not expressly adopted the servant's statements as true.

Ewaschuk, J. concluded his analysis by proposing a different standard for corporate and non-corporate employers. In his view, non-corporate employers are bound by the hearsay they obtain unless they expressly reject it on discovery. He said that the rules for when an officer's evidence binds the company as an admission are more complex. In his view: ${ }^{48}$

\begin{abstract}
"Where a corporate officer answers from his or her own personal knowledge, the answers will bind the company as its admission where the officer is a directing mind of the company or if not a directing mind the answers will bind the company unless the officer expressly states that the company claims the answers are erroneous. Where the corporate officer answers as to the knowledge of the company's servants or agents, the answers will bind the company as an admission if the knowledge was acquired during the course of employment or agency and the servant or agent remains connected with the company until the discovery of the corporate officer. In this situation, the corporate party is bound by this hearsay as an admission unless the corporate officer expressly claims on discovery that the information is erroneous. Finally, where the answers involve information received from unrelated third parties or former servants or agents, the company is not bound by its corporate officer's answers unless it expressly adopts them on discovery as accurate.
\end{abstract}

Of course, Ewaschuk, J.'s reasons are only of historical interest as he was overruled by his own Court of Appeal. But the inconsistency of his approach with the Nova approach (both are 1986 decisions), and the further inconsistency of both those approaches with the Ontario Court of Appeal's approach in Claiborne in 1989, all demonstrate that the law is far from well settled in this area. Interestingly, neither Ewaschuk, J. nor the Ontario Court of Appeal refer to Nova or MacGregor, but both refer to the Alberta case of Edmonton v. W.W. Sales Ltd., although the Ontario Court of Appeal rejected Ewaschuk, J.'s approach based on that case.

(c) The Old Alberta Case of Edmonton v. W.W. Sales

\footnotetext{
4. Claiborne Industries Ltd. v. National Bank of Canada (1987), 55 O.R. (2d) 289 (Ont. H.C.).

45. Edmonton v. W.W. Sales Lid., [1941] 3 D.L.R. 737, [1941] 2 W.W.R. 329 (Alta. S.C.).

46. Supra, note 44 at 321.

47. Black v. Hardwell, [1935] 2 W.W.R. 172 (Sask. C.A.), a case which states that hearsay can only be admissible against a party if he adopts it as true, but which did not deal with the evidence of an officer on discovery.

48. Supra, note 44 at 321-22.
} 
The 1941 decision in Edmonton v. W.W. Sales Ltd. is sort of a"lost case" in Alberta jurisprudence. It was referred to in argument in the Nova case, but not referred to in Brennan, J.'s judgment. As the approach taken in that case appears to be different from the Nova approach, the Hawrelak approach, and the Ontario approach, it should be discussed.

In Edmonton v. W.W. Sales, two employees of the corporate defendant informed the officer of the corporate defendant that they burned material in an ash can. The trial judge found that a fire which destroyed a building adjacent to the ash can shortly thereafter was started by a fire in the ash can. The plaintiff sought to read in the officer's testimony from discovery where he said that the employees told him that they had burned material in the ash can and then reported the fire. The corporate defendant objected to the evidence being used at trial on the basis that the corporate officer had not been asked whether he accepted or rejected that information. The trial judge, Howson, J., agreed. He referred to MacGregor, and without much discussion said: ${ }^{49}$

Upon the authorities, I have decided that the statements made by Fleming and Edstrom to Wilson are not admissible as evidence against the Defendant.

In the end, the admissibility of this evidence did not matter, as the judge was satisfied on other evidence that the defendant's employees caused the fire.

The Edmonton v. W.W. Sales case appears to be based on a rather literal reading of MacGregor. In MacGregor, the officer was expressly asked and expressly acknowledged that this information was information of the company. That evidence could be read in. In Edmonton v. W.W. Sales he was not, and the evidence could not be read in. That appears to be the only difference in the nature of the evidence. Interestingly, the officer was expressly asked the same question in Nova, and it is obvious from the exchange between counsel found in the Nova case that both counsel had MacGregor in mind.

The W.W. Sales case either stands for the proposition that no use can be made of an employee's evidence on discovery (which it was argued to mean in Nova), or it can be construed as adding a certain rigidity to the Nova approach. It can be reconciled with Nova if one takes the view that, pursuant to W.W. Sales, the examining lawyer must get the officer to agree that an employee's evidence is information of the company in so many words. If he does not, the fact that the officer speaks about that information on discovery is of no importance. It is inadmissible without an express acknowledgement that it is information of the company.

At first glance this requirement of a magic incantation seems absurd, but it can be defended. If an officer is being asked to say what an employee said, the officer is being asked to repeat hearsay. The law is suspicious of the reliability of hearsay. Requiring the examining lawyer to confirm that the hearsay is the company's information at least adds an element of reliability to it. If the company also has contrary information, that 
may well be brought out, thereby avoiding surprise at trial. Finally, it makes it clear to all parties that this evidence may be used at trial even though it is hearsay.

Whether or not these policy reasons appeal, Alberta law at present, arguably, is that it is mandatory to receive the officer's confirmation that evidence given by employees is information of the company, or else it will not be admissible at trial.

(d) The Use of a Notice to Admit Facts

Another possible approach to making employee's evidence binding involves using a Notice to Admit Facts in respect of an employee's evidence. It was argued to be the only approach in Nova, but not successfully. It is based on comments of Beck, J. (as he then was) in McLean v. C.P.R.:.$^{50}$

I suggest that it is one of the purposes of the rules that facts learned upon an examination for discovery of an employee - which as I have pointed out cannot be made use of as evidence against his employer - should in an appropriate case be made the subject of a notice to admit facts. One of the purposes of discovery is to obtain admissions. One of the purposes of a notice to admit facts is to save costs.

There are two Saskatchewan Court of Appeal cases to the same effect: Black v. Hardwell $l^{51}$ and Giddings v. C.N.R. ${ }^{52}$ These cases suggest that a Notice to Admit Facts is the only way to use such hearsay evidence at trial. However, in Hawrelak, Kirby, J. said he thought the use of a Notice to Admit Facts in this context was inconsistent with the MacGregor case, and expressly declined to follow Giddings. By contrast, in Opron, the Court of Appeal suggested ${ }^{53}$ that a Notice to Admit Facts would be helpful to an argument that the party who was forced to prove at trial facts which the other side's employee had stated in evidence on discovery would be entitled to costs no matter what happens. This would appear to overrule Kirby, J.'s comments in Hawrelak, however, in Opron, the Court of Appeal expressly declined to discuss the use at trial of an officer's answers in respect of an employee's evidence.

There is, of course, one major limitation with a Notice to Admit Facts. If the other party refuses to admit the facts then the only effect is that the other party may be punished with costs if that fact is ultimately proven at trial. A Notice to Admit Facts, therefore, does not help counsel prove a fact unless the fact is admitted.

\section{(e) Conclusion Regarding Information From Employees}

Alberta and Ontario practice are widely divergent. The Alberta practice has not recently been commented on by the Alberta Court of Appeal, as Nova was not appealed on this point. It may be that the Alberta Court of Appeal would reject Nova, and would follow an approach similar to the Ontario Court of Appeal's approach in Claiborne and Kirby, J.'s approach in Hawrelak, and treat all the officer's evidence as binding

McLean v. C.P.R. (1916), 10 W.W.R. 949 at 952.

Supra, note 47.

Giddings v. CNR (1919) 3 W.W.R. 15.

Supra, note 3 at 64 . 
admissions. In the Cana Construction case, ${ }^{54}$ Kearns, J.A. said in obiter that the purpose of Rule 214(1) is to gain formal admissions.

It is also possible that the Alberta Court of Appeal might view employees' evidence as given solely for the purpose of discovering information. There is a comment in Cana Construction to this effect, and in McLean v. C.P.R., ${ }^{55}$ Beck J.A. said that employees' examinations are for the purpose of discovery only. The Edmonton v. W.W. Sales case could be construed as supporting this proposition.

I think the law is sufficiently unsettled to make an appeal to the Court of Appeal worthwhile, no matter what a trial judge rules in respect of employees' evidence. In Opron ${ }^{56}$ the Court of Appeal expressly declined to rule on what use may be made of information an officer gets from an employee at trial. My own view is that the Nova approach is practical, and reconciles the competing concerns quite well. However, in using the Nova approach counsel would be prudent to ask the added question of whether the employee's information is information of the company, in order to avoid the Edmonton v. W.W. Sales case.

\section{Evidence Relating To Information Gathered From Others Not Within The Scope Of Rule 200(1)}

I have found no modern case which deals expressly with this category of information, except the trial decision in Claiborne. There, Ewaschuk, J. said: ${ }^{57}$

Finally, where the answers involve information from unrelated third parties or former servants or agents, the company is not bound by its corporate officer's answers unless it expressly adopts them as accurate.

This passage was implicitly overruled by the Court of Appeal in Claiborne, as it allowed information obtained by the officer from a fired employee to be read-in as an admission.

There is an old Alberta case somewhat on point. In Lea v. Medicine Hat (City), ${ }^{58}$ the Alberta Court of Appeal was called upon to address this issue, although on a rather unusual set of facts. In that case, a current employee of the defendant had also been an employee of the plaintiff. His name was Pyper. The plaintiff's counsel sought to have Pyper appointed as the officer of the defendant, and then examine Pyper on information Pyper acquired while working for the plaintiff, as well as on information acquired while working for the defendant. He would then examine Pyper and read in only that part of the examination which was favourable to the plaintiff. On those facts, Harvey, C.J.A. said that such a course was inappropriate. He said:.99

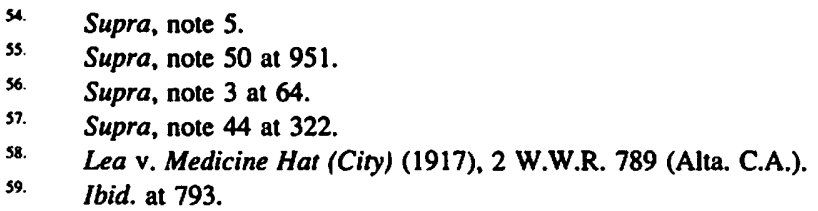


In Welsbach ... it was held that an officer of a company answering for the company could not be compelled to answer as to knowledge obtained outside of the company's employment. That principle appears to be implied in our rule 234 [equivalent to current Rule 200] which permits examination of employees who have information acquired by virtue of their employment. There is a present judgment against the plaintiff that he cannot get the information he denies against Pyper as a simple employee of the defendant by reason of the fact that the information was not acquired by virtue of his employment by the defendant. It seems clear that under the authority of the case cited no officer of the defendant could be required to inform himself from Pyper and communicate such information. It would seem to follow necessarily and certainly it is clear from the dicta in the cases cited, which are very instructive. that Pyper on being examined as the mouthpiece of the defendant could not be compelled to give information acquired by him outside his employment. [emphasis added]

Thus Lea appears to stand for the proposition that an officer need not disclose information learned by him outside the scope of his employment.

Lea was referred to as an authority for a somewhat different point by the Supreme Court of Canada in R. v. N.M. Paterson ${ }^{60}$ In the Paterson case, the Supreme Court of Canada was dealing with the issue of whether an officer of a corporation at trial could be compelled to give evidence in a prosecution against the corporation, or whether he could not be compelled because he is the directing mind of the corporation, and compelling him to give evidence would amount to corporate self-incrimination. The Supreme Court's judgment was written by Chouinard, J., who said it was not self-incrimination, and that the witness was compellable. In the course of delivering his judgment, His Lordship distinguished between the evidence of an officer of discovery where he is the "mouthpiece" of the corporation and evidence at trial. One of the passages he cites with approval impacts on the question of whether an officer must comment on discovery on matters which come to his attention outside of his duties as officer. He said: ${ }^{61}$

Finally, I believe that Amup J.A. in Corning Glass, ...has aptly distinguished evidence given on an examination for discovery by a person produced by a corporation and evidence given at trial by an employee or officer of that corporation. On discovery such an employee or officer is the corporation (Lea v. Medicine Hat 11 Alta. L.R. 380, [1917] 2 W.W.R. 789, 35 D.L.R. 109 (C.A.); Welsbach Incandescent Gas Lighting Co. v. New Sunlight Incandescent Co., [1900] 2 Ch. 1 (C.A.); Goodbun v. Mitchell, 37 Man. R. 451, [1928] 2 W.W.R. 594, [1928] 3 D.L.R. 709 (C.A.)).

Amup J.A. states at pp. 208-209:

In my view, there are fundamental differences between evidence given on examination for discovery of a person produced by a corporation for that purpose and evidence given at trial by a witness who is an officer or employee of that corporation. On discovery, the witness literally speaks for the corporation. He has been described, as long ago as 1902, as the 'mouthpiece' of the corporation: Morrison v. Grand Trunk Ry. Co. (1902), S 0.L.R. 38 (C.A.). The term was adopted with reference to a servant of the corporation, by Road, J., in Fisher v. Pain, [1938] O.W.N. 74 at 76, [1938] 2 D.L.R. 753n. As pointed out by Grant, J., if such a witness does not know the answer to a relevant question, he must inform himself from others employed by the corporation or from its records. Conversely, he may be examined only as to matters coming to his knowledge as an officer of the corporation. Knowledge which he has acquired otherwise than as such officer cannot be explored: Fisher v. Pain, supra. [emphasis added]

The proposition in Lea, supported by the dicta in Patterson, that a corporate officer on discovery has no duty to disclose information that came to him outside of his employment, is contradicted by a frequently cited decision of the Saskatchewan Court of King's Bench in Culver v. Lloydminster, ${ }^{62}$ which has been followed in Alberta. 
In Culver, MacDonald, J. did not refer to Lea. He ruled that although an individual party witness need not seek out information from third parties over whom he has no control, and never had control, nonetheless, if he in fact has information from such third parties, he must disclose it. He said: ${ }^{63}$

I cannot find any case, however, that goes so far as to hold that the defendant being examined for discovery must make inquiries from third parties over whom he has no control in order so to inform himself as to be able to answer the questions put to him, and I do not think that it is the law that he is so bound.

I am, however, of the opinion that a party being examined is bound to disclose anything of which he has knowledge or information at the time discovery is sought.

Bray on Discovery 134.

Culver thus stands for the proposition that one need not seek out information from third parties, but one must disclose any information from third parties one has. Although Culver dealt with the duties of a party litigant rather than the officer, its reasoning has been held to be equally applicable to the officer of a corporation. ${ }^{64}$ Culver was followed directly on point by Master Quinn in Al Oeming Invsts. Ltd. v. Floyd. ${ }^{65}$ It does not appear as though Master Quinn was aware of the Lea case. Culver was also followed on another point by Wachowich, J. in Ed Miller Sales \& Rentals Ltd. v. Caterpillar Tractor Company. ${ }^{66}$

In Wallace Neon Ltd. v. Tilden Corporation, ${ }^{67}$ the Lea case was referred to and distinguished as being restricted to its facts, and the Welsbach case on which Lea is based was distinguished as being a case dealing with interrogatories. There, the issue was whether Mr. Tilden, when produced as officer of Tilden Corp., had to answer questions dealing with knowledge he gained through his involvement with Tilden Rent A Car Ltd. Both Tilden companies were defendants, and Rent A Car's officer had been examined before. The B.C. Court of Appeal said that a witness being examined as an officer of a company must answer all questions relating to issues between the parties of which he has personal knowledge, including his own conduct, regardless of the capacity in which he gained the information, provided that he gained the information during the time he held office or was employed by the company. However, in that case, the B.C. Court of Appeal expressly stated that the question of hearsay information was not before them.

Due to the age of the Lea case, and the divergent modem authorities in the discovery area, I would suggest a modern Alberta court could follow either the Lea approach or the Culver approach. If the Culver approach were followed in preference to the Lea approach, or if an officer on discovery simply volunteers information obtained from third parties, even if he cannot be compelled to give it, an issue arises as to what use that information can be put to at trial.

Ibid. at 408.

R. and Minister of Highways v. W.C. Wells Construction (1969), 72 W.W.R. 121 (Sask. Q.B.). Al Oeming Invsts. Ltd. v. Floyd (1983) 43 A.R. 111.

Miller Sales \& Rentals Ltd. v. Caterpillar Tractor Company (1988), 57 Alta. L.R. (2d) 187.

Wallace Neon Ltd. v. Tilden Corporation (19) 47 W.W.R. 61 (B.C.C.A.). 
For example, what if an officious bystander phones highly relevant information in to the company when he has no duty to do so. What use can the other side make of that information? Should the information an officious bystander gives to a corporation with whom he has no connection be useable against the corporation as some evidence of a fact? What if it was the only evidence on a crucial issue, and the officious bystander cannot be located for trial?

If such evidence obtained from the officer on discovery were useable at trial, then hearsay evidence, which has no element of reliability at all from being a declaration against interest by someone associated with the company, would arguably become admissible at trial as some evidence, and might ultimately be determinative of a crucial issue.

On the other hand, if that information is the only information, then it is the best evidence available. Would it be fair to exclude that evidence if it is the only information available?

On the right set of facts this would be a very interesting issue.

\title{
III. DUTIES OF THE OFFICER APPOINTED PURSUANT TO RULE 214(2) IN RESPECT OF INFORMATION FROM EMPLOYEES
}

\section{A. PREPARATION BY INTERVIEWING EMPLOYEES}

In the MacGregor case ${ }^{68}$ Harvey, C.J.A. stated succinctly what preparation an officer must do before a discovery under Rule 214(1). He said"69

\begin{abstract}
When an officer of a company is called to give evidence on an examination for discovery he must inform himself of all the facts that are within the knowledge of the company so that he will be able to disclose them if necessary....
\end{abstract}

In Abel v. Cooke, ${ }^{70}$ Ewing J. said: ${ }^{71}$

There is no dispute concerning the general proposition that an officer selected by a corporation to submit to examination for discovery is duty bound to acquaint himself with the facts which are within the knowledge of other officers, servants or agents of the corporation who personally have knowledge of the facts or circumstances which knowledge they acquired in that capacity.

The rationale for this rule is given in Cobble v. Mills and Swatich, ${ }^{72}$ where Boyd McBride, J. said. ${ }^{73}$

The true principle is, I think, to be found in Ross on Discovery, Can. ed., at pp. 134 et seq, from which I now read the following passage:

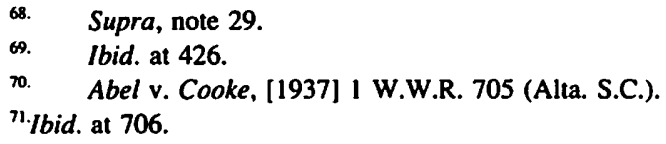


Moreover if the acts inquired about are such as in the ordinary course of business would be done by or known to his servants or agents he [the officer] cannot escape answering by saying he has no personal knowledge of the matter inquired into, but he must also make inquiries of his servants or agents and state the result of such inquiries. The principle is that their knowledge is his knowledge and he is therefore bound to answer to respect of that knowledge.

These principles were recently reaffirmed by Mr. Justice Dea in Opron, where he said: ${ }^{74}$

When an officer selected does not have the information required to answer a question he may be asked to inform himself and provide the questioner with the information he has received. He has a duty to inform himself and the several cases involving the procedure are well known and include $A$ bel $v$. Cooke ... [and] Cobble v. Mills....

The officer's duty to inform himself also extends to seeking information from former employees. In Abel v. Cooke Ewing, J. said: ${ }^{75}$

The effect of the authorities seems to be that, subject to limitations such as are indicated in the cases cited, an officer who is being examined on behalf of a corporation is not relieved from the duty to inquire merely because an employee who has the required information gained in the course of his employment has ceased to be in the corporation's employment.

However, the corporation is not automatically bound by that information. In addition to the issue of whether his information is the company's information (see discussion of Nova above) it is open to the corporation to state that the information is mistaken or wrong. In Abel v. Cooke Ewing, J. said: ${ }^{76}$

After reading the Rules and such authorities as have been referred to me, and such authorities as I have been able to find, I feel bound to hold that Mr. King is bound to inquire and to state the results of his inquiries 'protecting himself in some way by the form of his answer' or by making it clear that the answers given to him are mistaken or wrong.

In that case the officer was afraid a former employee who had been dismissed would make up information damaging to the corporation.

The principle that the company may state that the information is wrong seems straightforward enough, except that Ewing, $\mathrm{J}$. went on to limit the inquiry if the officer states that the information is wrong. He said: ${ }^{77}$

But I am of the opinion that if Mr. King says that in his belief certain statements are in fact mistaken or wrong or untrue he cannot be asked as to the evidence of these facts.

I would think, however, that he could still be asked what other information he has on the topic. Support for my point of view can be found in Gidding v. C.N.R., ${ }^{78}$ where Lamont J.A. said. ${ }^{79}$

If for any reason the information is believed not to be accurate, all the officer being examined has to do is to state that he is informed that such and such are the facts, giving the name of the officer, agent or servant who furnished the information.

lbid. at 711.

lbid.

Gidding v. C.N.R., [1919] 3 W.W.R. 15 (Sask. C.A.).

Ibid. at 18. 
If the former employee cannot reasonably be located the duty of inquiry comes to an end. In Cobble v. Mills, ${ }^{80}$ Boyd McBride, J. again cited Ross on Discovery and said: ${ }^{81}$

\begin{abstract}
Where the agent is no longer under the party's control or is in such a position that it would not be reasonable to force the party to communicate with him, the party may be relieved from the obligation to make inquiries of him.
\end{abstract}

The officer may not, however, be obliged to ask questions of employees about knowledge which they happened to acquire outside the course of employment. ${ }^{82}$

Finally, there is no duty on an officer to inform himself from people with whom he has no connection. In Curlett v. Can. Fire Insurance, ${ }^{83}$ Ewing, J. said that there is no duty on the officer to inform himself from someone who is not an officer, employee or agent or a former officer, employee or agent. ${ }^{84}$ He adopted the reasons of MacDonald, J. in Culver, who said: ${ }^{85}$

I cannot find any case, however, that goes so far as to hold that the defendant being examined for discovery must make inquiries from third parties over whom he has no control in order so to inform himself as to be able to answer the questions put to him, and I do not think that it is the law that he is so bound.

There is an issue about whether an officer must disclose information of which he is aware that came to an employee from outside the scope of his employment. ${ }^{86}$

From the above cases it can be seen that an officer must prepare for discovery by interviewing relevant employees or former employees, so that he can speak of "all facts that are within the knowledge of the company", to quote Harvey, C.J.A. If he has not done so, he is required to make such inquiries and to report on the result of such inquiries regardless of whether he likes the information or not. Alberta practice is to do this by way of undertakings given at the examination for discovery. If he does not like the information he may disclaim its truth when he discloses the information.

\title{
B. PREPARATION BY READING THE TRANSCRIPTS OF EMPLOYEES WHO HAVE BEEN EXAMINED
}

In the Nova case, the Plaintiff agreed that all the employees' evidence at examination for discovery was information of the Plaintiff. Justice Brennan said: ${ }^{87}$

80. Supra, note 72.

s. Ibid. at 798.

82. Lea, supra, note 58; Culver, supra, note 62.

83. Curlett v. Can. Fire Insurance, [1938] 3 W.W.R. 357 (Alta. S.C.).

s. The issue of who is an agent for the purposes of the officer's duty to inform himself from the company's agents is discussed in Ed Miller Sales and Rentals Ltd. v. Caterpillar Tractor (1988), 57 Alta. L.R. (2d) 187, 88 A.R. 110. This can extend to outside consultants and professionals employed by a corporation, Canadian Utilities Lid. v. Mannix Ltd. (1959), 29 W.W.R. 289 (Alta. C.A.).

8s. Supra, note 62 at 408.

86. See, infra, the discussion of evidence relating to information gathered from others not within the scope of Rule $200(1)$.

87. Supra, note 13 at 20. 
It is my further view that having regard to the said discussion and the admissions made therein it would have been a complete and unnecessary waste of time, effort and cost to require the defendant to put each and every answer of each and every employee to Olafson to obtain his admission on his examination that the answers given were the information of the plaintiff.

Based on this passage it would seem reasonable to save time by asking the officer to advise whether the transcripts of previously examined employees are the information of the company.

However, in Opron, Dea, J. was very critical of such an approach. In that case the following question was asked on discovery: ${ }^{\mathbf{8}}$

Do the answers that those employees [Campbell, Thiessen and Ruttan] have given on their Examinations for Discovery in this action constitute information that you have obtained as the Defendant's officer for the purposes of your Examination for Discovery?

The officer refused to answer that question. He was therefore asked to do the following:

Mr. Nicolson, would you please look at the transcript of Mr. Campbell's examination and ask him each of the questions he was asked on that examination and obtain each of the answers to all of the questions that were asked from page 2 to page 428 and tell me his answers, please.

Dea, J. said: ${ }^{89}$

These questions constitute a travesty of acceptable procedure and are rejected in toto.

In Dea, J.'s view: ${ }^{90}$

\begin{abstract}
The correct procedure is to ask a particular question to the selected officer. If he is unable to answer the question because he does not have the information, he may be required to inform himself and thereafter to provide the information he has obtained to the questioner. He is under no obligation to do the kind of compendious labour which the plaintiff wishes to impose upon him. The plaintiff is at liberty to go through the discoveries of the three employees and put to the selected officer the various questions in proper form question after question and answer after answer. The 'short cut' procedure proposed by the plaintiff as aforesaid is entirely inappropriate and is unacceptable.
\end{abstract}

Even the procedure recommended by Dea, J. must be followed carefully. In Yanik, ${ }^{91}$ MacDonald, J. refused to allow a question to an officer based on an employee's question and answer at a previous discovery where the officer was asked "Will the defendant company admit it as a true statement?"

In Opron, the Court of Appeal did not overrule Dea, J. but suggested that it may be reasonable to ask an omnibus question. However, it also said that it is not fair to compel an officer to answer an omnibus question about an employee's evidence. If the officer refuses to answer an omnibus question, then the questions must be asked individually. If that happens, costs may be awarded against the party producing the officer for the lengthy discoveries so required. The Court of Appeal's judgment on this point is brief, and worth quoting in its entirety: ${ }^{22}$

$\begin{array}{ll}\text { 88. } & \text { Supra, note } 3 \text { at } 153 . \\ \text { 89. } & \text { Ibid. } \\ 90 . & \text { Ibid. } \\ \text { 91. } & \text { Supra, note } 7 . \\ \text { 92. } & \text { Supra, note } 3 \text { at } 64 \text {, per Côté, J.A.. }\end{array}$


During argument, counsel agreed that Opron could force the Government's officer to ask Government employees about topics on which they had already been examined, and then to give Opron the resulting hearsay himself. However, the Government objected to Opron's lumping all the answers of one employee in one question to the officer. It argued that that had to be done question by question.

A sufficient solution is that a witness may object to a multi-part question, and may have it broken down into separate questions. He may answer multi-part or omnibus questions if he wishes. Sometimes it is reasonable to ask them. Often parties would be wise to save time and money by agreeing to frame and answer such questions. But the witness cannot be forced to do that, for reasons of faimess.

Therefore, as the Government objects, Opron can compel answers about the employees' information only one question at a time. Presumably Opron could give the Govermment a few weeks' prior notice, warning the officer to inform himself about each question earlier asked on the discovery of Government employee $X$. Then Opron may (if it wishes) put each question from that employee's transcript separately to the officer. It may ask him what information the Government has from that employee on that question. I do not decide what use may or may not be made of those answers at trial.

But costs are a separate question. That question-by-question process might take a week to cover several employees' transcripts. I wish to say nothing which would prejudge costs of discovery in any way. After trial, the trial judge or the taxing officer might conclude that the Government should not get costs of that pedestrian week, and indeed should pay most of them instead. That might be especially so if Opron used an appropriate Notice to Admit. That might be true even if the Government won the trial. That would depend on facts and circumstances not available now and not argued now.

Thus the two very different trial level views of what is appropriate have been reconciled into an intermediate approach set by the Court of Appeal in Opron. As a result of Opron a good practical strategy for the examining lawyer to follow prior to the examination for discovery of an officer would be to identify to opposing counsel those employees who the lawyer knows have information he would like the officer to provide so as to ensure the officer will properly fulfil his duty to come informed to the examination for discovery. In Opron, Côté, J.A. suggested that Opron could give the Government a few week's prior notice, warning the officer to inform himself about each question earlier asked on the discovery of Government employee X. I would recommend that course be followed. This approach assumes that employees would be examined first, as is the custom in Alberta.

\section{ADOPTING AS FACT THE EVIDENCE OF EMPLOYEES WHO HAVE BEEN EXAMINED}

Must the officer adopt as fact the evidence of employees who have already been examined? In Alberta, the answer appears to be "no". In MacGregor, ${ }^{93}$ Harvey, C.J.A. said that an officer is only obliged to state what the company's information is. He is not obliged to state what is a fact based on an employee's statement. Harvey, C.J.A. said:94

Now that of course is something which he [the officer] does not know and could not be expected or required to make a statement of what the fact was. The Rule does not require that. It is the function of the jury or the Judge, not the party to decide what the true facts in dispute are.

In Yanik v. Conibear, 95 MacDonald, J. said of an officer's obligation respecting adopting employees' evidence in the context of preparing for his own discovery: ${ }^{96}$ 
... this does not involve any obligation on his part to accept or reject statements elicited from the servant by counsel for the opposite party on examination for discovery.

A passage to the same effect is found in Nova. ${ }^{97}$

\section{STATING WHETHER THE EMPLOYEES' STATEMENTS ARE BELIEVED}

This was expressly addressed in MacGregor.$^{98}$ Harvey, C.J.A. said that an individual being examined is obliged to state his belief. A corporation's officer is not. He said: ${ }^{99}$

So far as he refers to questions of belief, that could seem to have more application to the case of a party who is being personally examined, who might be asked to express a belief. Certainly the belief of the officer being examined could not be the belief of the company, belief is a state of mind; a corporation does not have a mind and the belief of the individual officer could be of little value.

Harvey, C.J.A. went on to say that it is proper for the officer to answer that something is the company's information and that the company has no information to the contrary.

\section{E. STATING THE COMPANY'S POSITION ON THE STATEMENTS OF EMPLOYEES}

This was also expressly addressed in MacGregor. ${ }^{100}$ The company need not state its position on the statements of employees. Harvey, C.J.A. made comments on the following question about the company's position on an employee's statement: ${ }^{101}$

"Then Mr. Hellman said: I am entitled to get the CPR's position, I want to know whether it accepts the conductor's statement."

Harvey, C.J.A. said that the response to that question of "It neither accepts it or rejects it" was proper, and was the only response which could be required of the officer.

\section{CONCLUSION}

The use to which an officer's evidence may be put at trial is uncertain. This is particularly so in the case of answers an officer gives in respect of information obtained from employees and others.

In Alberta, the Nova approach is generally followed at present. In my view that approach of allowing the examining party to read in all evidence from the officer on discovery as some evidence of the facts alleged reconciles the competing interests well. The Ontario approach of binding the company with all the information it has from employees absent a disclaimer appears to me to be too harsh to the company. Equally, the approach of having employees' statements useful only for discovering information, as opposed to being useable at trial as some kind of evidence, reduces the value of the discovery process, and would tend to unduly prolong trials.

\begin{tabular}{l} 
97. $\quad$ Supra, note 13 at 17. \\
98. Supra, note 29. \\
99. \\
100. Ibid. at 427. \\
10t. $\quad$ lbid. \\
\hline
\end{tabular}


The Nova approach is practical, and will hopefully be blessed by our Court of Appeal. Until then, however, uncertainty will remain in Alberta about the use to which an officer's evidence may be put at trial.

The duty of an officer in respect of information in the possession of corporate employees is more certain. He must prepare for discovery by interviewing employees and former employees if it is practical to do so. If he has not done this preparation, he can be asked by examining counsel to do it. He can also be obliged to deal with transcripts of employee's evidence, at the very least, on a question by question basis. He need not, however, adopt their evidence as fact nor need he state whether he believes their evidence, or state the company's position on their evidence. An officer has no duty to seek out information held by people who have never had a connection with the company. However, whether he must disclose information from third parties of which he is already aware is still unclear. 